\title{
CANCER AND CAM (COMPLEMENTARY AND ALTERNATIVE MEDICINE) PARADOX
}

\author{
Ayşe ÖZDEMİ ${ }^{1}$, Yılda Arzu ABA $A^{2}$ \\ ${ }^{1}$ Uşak University, School of Health, ,Department of Nursing, Uşak, Turkey, \\ ayseozdemir1970@hotmail.com \\ ${ }^{2}$ Bandırma Onyedi Eylül University,Faculty of Health Sciences, Department of Biochemistry, \\ Bandırma, Turkey, yildaarzum@hotmail.com
}

\begin{abstract}
Herbal therapy or phyto therapy have been commonly used to treat patients with herbs for thousands of years around the world particularly in such regions as Anatolia and China. Herbal drugs are believed to be useful and harmless among the public. The interaction of herbal products and cancer drugs is a big problem encountered during cancer treatment and its effects are not well-known. Cancer treatment is important and must not be interrupted. In this review, we discussed the paradox of the interaction of herbal products and cancer drugs in the light of experimental and epidemiological evidences as well as the impact of online news regarding the herbal medicines for cancer treatment.
\end{abstract}

Keywords: Cancer, Phytotherapy,Paradox, alternative medicine

\section{INTRODUCTION}

In our society, cancer is a disease constantly believed to require a miracle and feared to result in death and thus attempted to be cured by Folk Therapy or natural methods like "honey miracle" on TV channels. Its historical progress shows that the first evidences of cancer cases date back to Edwin Smith papyrus and mummies in Egyptfrom 3000s B.C, but the term cancer used for "unhealed" structures was first described by Hippocrates in 300s B.C. Approximately 500 years after Hippocrates who named the painful, ulcer-forming red tumors "carcinos" or "carcinoma", Galen named these tumors "cancer" as he likened them to crabs [1] In physiological sense, cancer is the uncontrollable growth of a cell which has the capacity to divide a specific number of times in its lifetime, and the accumulation of such cells to form tumoral masses. Primary carcinogenic factors are smoking and alcohol consumption, viral diseases, sunlight, chemical substances and air pollution and malnutrition.With respect to the principle "there are no diseases, there are patients", many types of cancer are present and each of them grows at different rates and requires different treatment methods [2]

\subsection{Complementary and Alternative Medicine (CAM) Methods in Cancer Treatment}

Many treatment methods outside modern and scientific treatments are generally known as Complementary and Alternative Medicine (CAM) methods. Although cancer treatment is considered anunending road among the public, many cancer types can be almost fully cured in early stages with 
cancer treatment in modern medicine. Nevertheless, especially complementary therapy plays an important role in cancer treatment [3]

More than 200 Complementary Therapy methods are classified into five categories by the National Center for Complementary and Alternative Health (NCCAH) $[3,4]$

1. Alternative and medical system (traditional Chinese medicine including acupuncture and qigong, homeopathy, ayurveda)

2. Body-mind therapy (bio-feedback, hypnosis, relaxation/meditation, music, imagery, prayer/spirituality)

3. Biologically based therapies (herbal therapy, high-dose vitamins, special diets)

4. Energy therapies (therapeutic touch, reiki)

5. Manipulative and body-based therapies (massage, exercise, chiropractic, hydrotherapy, reflexology, acupressure)

Although Complementary and Alternative Therapy methods are used interchangeably, Alternative Therapies are used as a standalone treatment in cancer treatment while Complementary Therapies are used as an add-on or complementary therapy to cancer treatment [3]

\subsection{Biologically Based Cancer Treatment from CAM Methods,Phytotherapy}

Treatment with plants, or phytotherapy, is made up of the words "plant" and "treatment" [5 ] Phytotherapy contributed to the drug development by minimizing the side effects after the development of basic medical sciences such as chemistry and biochemistry, and thus the increase in pharmacological and experimental studies in the historical process. In 1650s, in his grand medical book named "el-Kânûnfi't-T1bb (Canon of Medicine) which is regarded as a reference book, Avicenna described the systematic classification of diseases and drugs, administration methods of drugs and the drugs of plant, animal and mineral origin, and mentioned phytotherapy in disease treatment. Although not standardized, about 650 of more than 12,000 species and sub-species, 1251 types and 74 families of herbs grown in Turkey (many herbs such as mint, thyme, sage, bayleaf, cumin, aniseed, lime flower, fennel seed, rock cherry, rhus and juniper bark are exported) have been used in folk medicine for years $[5,6]$ In fact, $25 \%$ of many substances we use as drugs are of plant origin. The treatment method employed for years by using herb parts has today transformed into "Contemporary Phytotherapy" that describes the transition from herbal treatment to herbal drugs. Due to the difficulty and costliness of cancer treatment and its side effects that cause health discomfort, there is an increasing tendency to apply natural products and herbal treatment or phytotherapy that dates back to ancient civilizations like Sumerian Civilization founded in Mesopotamia [5,6,7] Phytopharmaceutics and Phytotherapeutics are in a certain pharmaceutical form and have the same meaning and content and are orally administered herbal drugs. However, scientific studies about herbal drugs prepared from phytotherapeutics are not as sufficient as phytopharmaceutic studies. Therefore, the use of phytotherapeutics is based on traditional treatment methods and allowed only for minor indications. As herbal drugs are recommended for mild infections, it will be more acceptable to use the term Complementary Therapy rather than Alternative Therapy [5,6] 


\section{DISCUSSION}

Today, reactions against the use of synthetic drugs due to their severe side effects as well as medical and financial problems raised the interest in Medical and Aromatic herbs again. Herbs containing thousands of phytochemicals such as essential oils, capsaicins, tannic substances, minerals, glycosides, alkaloids, saponins, flavonoids and vitamins are commonly used against diseases ranging from simple disorders like cold to severe diseases such as cardiac disorders, diabetes, rheumatic disorders and cancer $[5,8,9,10]$ According to World Health Organization, around 50\% of the world population benefited from traditional medical methods by using many kinds of herbs in 2000 . Moreover, many people prefer herbs to medical drugs because herbs are deemed safer as they are obtained by natural methods. They consider herbal drugs as an alternative to medical treatment. In African and Asian countries where access to physicians and drugs is difficult, herbal treatment is more commonly practiced than medical treatment. In the USA, on the other hand, herbal drugs are regarded as nutritional supplements or nutraceuticals and have not been controlled by FDA until recent years.Thus, the use of herbal drugs have become uncontrollably widespread in Turkey and in the world [5,11] For stomach-aches that may be caused by various factors from a simple spasm pain to intestinal obstruction, drinking mint and lemon tea before seeing a doctor displays the prevalence of natural methods among the public. Many people believe that all natural herbs and foods are safe. Therefore, they do not consider that taking these natural plants and foods as a supplement to the treatment can be wrong in cancer disease as they believe to be facing death. However, these herbs and foods may interact with drugs taken during medical treatment, thereby causing severe side effects. Specialists take this into account and state that naturality does not necessarily mean full safety [12]

Contrary to the recommendations of authorities regarding the use of herbal products in simple diseases, they are mostly used in chronic cases such as asthma, hepatic diseases, HIV, rheumatic disorders and breast cancer. In addition to their prevalence among the public, the use of herbal treatment methods is also common and acceptable in healthcare communities as indicated by the fact that $40 \%$ of the drugs marketed from 1983 to 1993 were of plant origin and constituted $50 \%$ of the prescribed drugs according to the study of National Cancer Institute for "Effective Treatment In Cancer" in the USA, a licensed herbal drug ranked $7^{\text {th }}$ among the most-prescribed drugs in Germany, and the practice of physician-based herbal treatments increased in health websites $[11,13]$ In a study with cancer patients, it was found that $63 \%$ of the patients used either complementary or alternative therapy methods at least once [14] As a result of increasing fear due to feeling threatened by cancer and the adverse effects of chemical drugs taken, complementary medical methods continue to be practiced by the patients.

\subsection{Phytotherapy Practice in Cancer and Impact of Media}

Due to the interest of medical doctors in phytotherapy, the despair of cancer patients and their relatives, the adverse effects observed during chemotherapy, the news regarding cure-all type drugs in the media and the skilful natural product sales representatives, orientation to healers and herbalists have increased. In internet search, the phrase "Herbal Therapy in Cancer" gives 382,000 results. Most of these websites contain articles about cancer treatments and the harms of chemotherapy written by people including specialists and general practitioners, dieticians, herbalists, phytotherapists, sales representatives, foreign healers and uneducated salespeople who market the herbal mixes they prepare in their villages. In these websites, some herbs are occasionally featured and herbal mixes such as 
extracts, pastes, capsules, syrups or elixirs prepared from these herbs are marketed without the control of Ministry of Health. Due to the news on media trying to convince people that herbal products have supernatural effects and treatment with these products causes less side effects as compared to chemotherapy, sufficient data are not available about food supplements prepared by nonpharmacological methods, their uncontrolled sale, why and how much they are used and whether they lead to dangerous side effects or not.

There are various information and instructions in the websites described as media. For example, following statement that may affect the chemotherapy process was encountered in a website: "I object to the practice of chemotherapy in cancer patients. Insisting to apply a treatment method that leads to so many side effects is against my understanding of being a doctor." In the same website, it is also commented: "No, you are not a cancer patient. You are just diagnosed with a mass in your pancreas. So what is recommended to you for this disease that has not progressed yet? Treatments that will destroy your immune system." [15]

In another online blog, a herb is introduced together with its picture and the comment: "My mother's cancer that had advanced to a degree where medical solution was impossible directed us to alternative medicine. Just then, with a little research I reached this miraculous information. Thanks to this cancer weed (Figure 1), she overcame throat cancer when she was on the eve of death." [16]

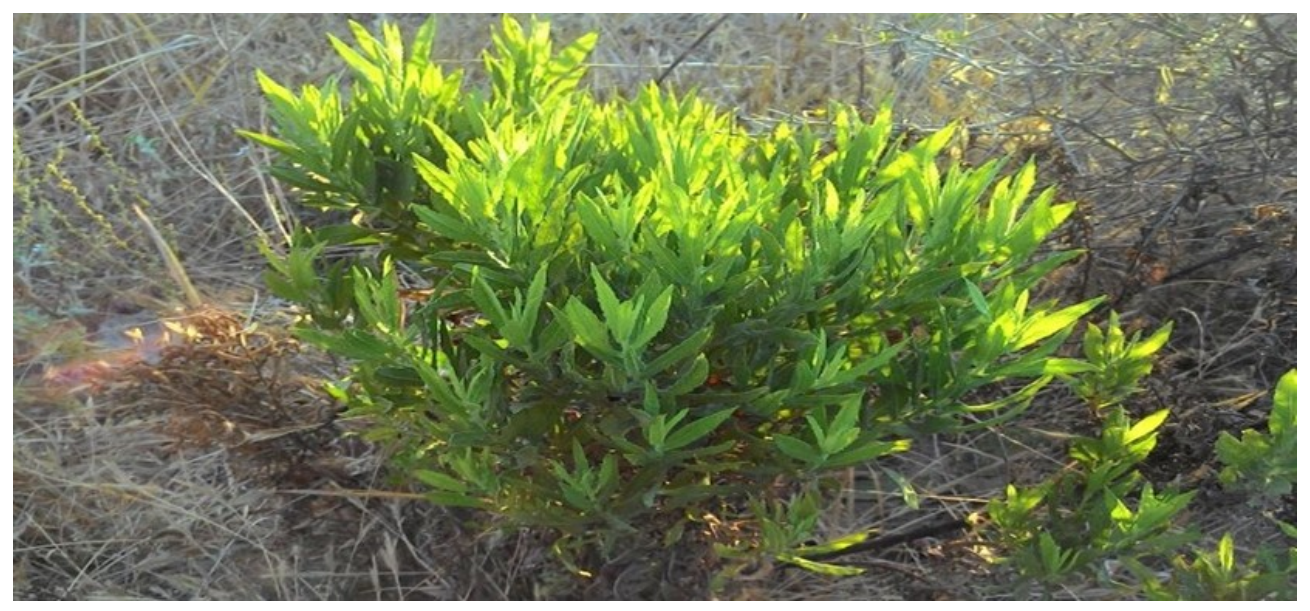

Figure 1.Cancer weed

In the website of a newspaper, it is claimed: "While applying chemotherapy to our patient suffering from soft tissue sarcomas with methastatic spread to lungs, the cancer spread to the brain as well. To the patient's chemotherapy treatment, I also added phytotherapy that I use especially in the cases of spread to brain, and the mass in the brain disappeared in the $4^{\text {th }}$ month of phytotherapy." [17]

In a woman-oriented website, a post claims "Incredible plant 100 times more effective than chemotherapy: dandelion" and emphasizes that this plant is a remedy for cancer [18] .

In another online blog, it reads: "Hello, dear being. You found out today that you have cancer. You seek medical treatment, it is your choice. Cancer is not a disease; therefore all the medical methods are violence-based" [19]. Sometimes referring to the food we consume daily, it is also claimed that some vitamins terminate cancer: "Most of the time, chemotherapy itself is carcinogenic. High doses of vitamin $\mathrm{C}$ are poisonous especially for cancer cells. This is what chemotherapy does 
too, but vitamin C does not damage healthy cells, cause nausea and hair loss. They only help recover" [20].

And sometimes medical methods are claimed to be completely harmful and patients are directed to alternative methods. "Put an end to cancer with the drug X. Chemotherapy is poison. Chemotherapy is not a treatment, it is death sentence. I have been investigating the effects of the drug $\mathrm{X}$ for 20 years and I admire it. I admire this water of life given by Jesus to humans. The drug X guarantees you $100 \%$ survival after 6 months of treatment, while medical practices guarantee average 5\% survival" [19].

Commonly addressed topics in these websites are as follows:

- Cancer not being a disease;

- Cancer patients' lack of belief in chemotherapy;

- Instinct of the patient relatives to help and find a new treatment method;

- Capability of salesmen to market their product even for once;

- Belief in the harmlessness of therapies with herbs collected from nature;

- Supernatural effect of herbal therapy against cancer;

- Patients and patient relatives relying on news for advertisement purposes rather than medical news;

- Belief that patients are used as subjects for cancer drug studies.

Side effects observed as a result of these herbalist drugs which are claimed to be produced by natural means and used without control during chemotherapy affect the patient's health negatively. Herbal products recommended innocently instead of cancer drugs produced after years of drug development studies costing millions of dollars and introduced to the market may sometimes worsen the disease. The interaction between drugs and herbal products which are easily accessible in Turkey and many other countries in the form of extracts is not well known yet. Furthermore, as they are not standardized, there is no sufficient scientific infrastructure and database regarding the life, side effects and other pharmacological characteristics of herbal products [11]. Many studies are conducted to confirm that the substances of plant origin known to be antioxidants against cancer for years have positive effects in ceasing the growth of cancer cells. Nevertheless, it is not possible to reach a final and definite conclusion regarding the effects and drug interactions of these antioxidants of plant origin. In a study, in case of the intake of exogenously-administered drugs such as quercetin, gallic acid and catechin which are known to have good antioxidant activity in high doses and especially in the presence of metal ions, these antioxidant substances were observed to show pro-oxidant activity and cause cell death and DNA damage in high concentrations [21].

The interaction between drugs and herbal groups causes severe side effects, and the most important drug group that may interact with herbal products is anti-cancer drugs as herbs may hinder cancer treatment. In addition to severe side effects during the concomitant use of herbs and drugs, they also cause toxicity and negatively affect body systems. Drugs used in cancer treatment such as irinotecan and imatinib interact with herbs as well. If the herb St. John's Wort (Hypericumperforatum) is taken during chemotherapy, it induces CYP3A4 which is one of the Cytochrome P450 system enzymes metabolizing the drugs in the liver (because CYP3A4 is also a substrate of chemotherapy drugs such as cyclosporine) and leads to a decrease in the concentration of cyclosporine administered. Echinacea inhibits CYP3A4 and increases the concentration of drugs such as cyclosporine. Grapefruit and St. John's wort are also known to interact with drugs metabolized by the Cytochrome P450 enzyme system. When ginseng is used with hormonal treatment, it has estrogenic activity. As it may 
increase estrogen and cause estrogen-associated vaginal bleeding and thromboembolism in breast cancer patients, the use of ginseng is definitely not recommended in concomitant with hormonal treatment [ 12,22,23,24] Cases of hepatic insufficiency associated with the use of Ganoderma Lucidum (Reishi) resulting with death were reported in medical literature. It acts on hepatic cytochrome enzymes and reduces the effects of anti-nausea drugs, thus it is definitely not recommended during chemotherapy [25 ] Many patients tend to buy herbal products marketed through TV and internet ads due to the fear of death or the desire to stay alive longer; they hide from their doctors the fact that they use such herbal products or associate the side effects with chemotherapy drugs and do not report them. From this aspect, it is difficult to detect the extent of herb-drug interactions $[11,22]$.

In 2001, the likelihood of herb-drug interaction was determined according to a scale developed by Fugh-Berman and Ernst for the likelihood of herb-drug interaction. The likelihood of herb-drug interaction is assessed by using a 10-point scale consisting of 10 criteria where each item is given 1 point. According to this scale, 10 criteria includes the following: Herbs used with the drugs are wellunderstood and their time and dose are known; their chronology is completed; their side effects are accurately and clearly identified; observation duration of the side effects of the drug; the end of interaction following discontinuation of the drug and whether side effects recur as a result of reexposure. Results with 8-10 points are assessed as "most likely", results with 4-7 points as "likely" and results with 0-3 as "interaction unlikely" [22]. We must have sufficient information regarding both the drug administration and the chemical properties of the herb. To assess this interaction is not always possible; therefore influential people in oncology approached herbal therapies with suspicion and encountered severe side effects that were thought to occur as a result of the common use of these products, and had to change their treatment methods or interrupt the patient's treatment. It is stated by oncology authorities that beta-caroten which has proven antioxidant activity facilitates lung cancer instead of preventing it in smoking people; antioxidants may reduce the effect of chemotherapy and radiotherapy; vitamin and mineral-mixed drugs may be harmful to cancer patients with bone metastase; overuse of garlic may decrease the efficiency of chemotherapy when taken with a blood-thinning drug called Coumadin; Gingko biloba and stinging netle may cause bleeding and mix with the side effects of chemotherapy; the herb Echinacea may decrease the efficiency of such drugs asolantaxol, vincristine, vinblastine,tarceva, irinotecan,cyclophosphamide, etoposide metabolized in the liver, therefore such herbs must not be taken with chemotherapy [25,26] It was demonstrated in a study that, in the event of interaction of a drug called Tamoxifen and the drug substance "genistein" found in soy and known to be a phytoestrogen,genistein inhibited the therapeutic effect of tamoxifen in a postmenopausal breast cancer model [27] It is also stated that even major healthcare organizations have difficulty in controlling these products, and toxic substances may have mixed in such herbs and thereby causing severe bleeding and death cases [5] In the final declaration of biennial Symposium on Medicinal and Aromatic Plants, it was emphasized that different studies were conducted on these herbs in different disciplines and the herbal drugs that only pharmacists are authorized to make should be standardized [28] Whether in Chinese Medicine, in Indian Medicine or in Traditional Herbal Medicine practiced in Anatolia, it is a fact that these therapies are common and used without control among the public and interrupt the medical treatments. Prevalence of herbal treatments and introduction of many herbal therapies into pharmacopeias on one hand, and interruption of cancer 
treatments and occurrence of severe side effects as a result of uncontrolled herbal therapies on the other hand show the phytotherapy paradox in cancer.

\section{CONCLUSION}

With regard to Contemporary Phytotherapy or European Herbal Therapy practiced in compliance with Modern Medical System, European countries published monographs containing the characteristics of herbal products such as chemical formula, activity, dosage, indications and contraindications, and started to manufacture the herbal drugs in accordance with Good Manufacturing Practices (GMP)rules [11] .However, in Turkey where folk medicine has carried on as a tradition since ancient times, deficiencies are observed regarding phytotherapy due to the marketing of the products by uneducated people, the effects of the herbal products, their interaction with other drugs, lack of follow-up in terms of price and activity, lack of control of the products imported from countries like China and India in terms of quality, abundance of companies trying to sell these products to helpless cancer patients etc. In order to ensure the safety of phytotherapy in traditional medicine especially in disadvantaged cancer patients, side effects, toxic effects and drug interactions of these herbs should be chemically and pharmacologicallyunveiled in a much clearer manner.

\section{REFERENCES}

[1] ***, Health Tought and Medical Culture Platform, http://www.sdplatform.com/Dergi/770/PersKralicesi-Atossa-ile-gecmisten-gelecege-kanserin-yolculugu.aspx

[2] ***, Bilkent University Health Center, http://bilheal.bilkent.edu.tr/aykonu/ay2005/apri105/kanser.html

[3] Yıldırım Y.K., Fadıloğlu Ç., Uyar M., Palyatif Kanser Bakımında Tamamlayıcı Tedaviler, A $\breve{g r l, ~}$ 18 (2006), 1, pp. 26-32 http://www.journalagent.com/agri/pdfs/AGRI_18_1_26_32.pdf

[4] ***, National Center for Complementery and Integrative Health, https://nccih.nih.gov/health/whatiscam/chinesemed.htm

[5] Ersoz T., Bitkisel ilaçlar ve gıda takviyeleri ile ilgili genel yaklaşım ve sorunlar. MISED 27 (2012), 28, pp.11-21.

[6] Şarışen Ö, Çalışkan D,Fitoterapi, Bitkilerle Tedaviye Dikkat (!) STED 14 (2005), 8, pp.182

[7] Esin Kahya, El-Kanun FitTıbb İkinci Kitap, Atatürk Kültür Merkezi Yayınları, İstanbul, Turkey, pp. 28-32

[8] ***, Nature Human Co-operation Association, http://www.dogainsanisbirligidernegi.org.tr/makaleler/Gecmisten_Gunumuze_Tibbi_ve_Aromatik _Bitkiler.pdf

[9] Özdemır A, Bayşu Sözbılır N, The Effect of Mentha Spicata L. Dry Powder and its Different Types Extracts on Certain Biochemical Parameters and Total Anti-oxidant Capacity, Kocatepe Vet J, 9 (2016), 1, pp.12-18 
[10] Faydaoğlu E, Sürücüoğlu M,S., Geçmişten Günümüze Tıbbi ve Aromatik Bitkilerin Kullanılması ve Ekonomik Önemi, Kastamonu Üni., Orman Fakültesi Dergisi, , 11 (2011), 1, pp.52- 67

[11] Gürün M,S., Bitkisel Tip, ANKEM Derg 18 (2004), 2, pp.133-136.

[12] Joshi R, Medhi B., Natural product and drugs interactions, its clinical implication in drug therapy management, SaudiMed J. 29 (2008), 3, pp. 333-9.

[13] Coskun M, Goker AH., Bitkisel ürünlerde analizin önemi, MiSED 27 (2012), 28, pp.30-34.

[14] Sparber A, Bauer L, Curt G, Eisenberg D, Levin T, Parks S, Steinberg SM, Wootton J, Use of complementary medicine by adult patients participating in cancer clinical trials, Oncol Nurs Forum 27 (2000), pp.623-630.

[15] $\quad * * *, h t t p s: / / w w w . u m i t a k t a s . c o m / t e d a v i l e r / k a n s e r / k a n s e r-t e d a v i s i$

[16] ***, http://www.keyifliyemektarifleri.com/manisa-akhisar-lutfu-acet-kanser-otu-kanserekesin-cozum

[17] ***, http://www.mesajhaber.com/?haber,20163

[18] ***, http://www.hthayat.com/saglik/haber/1028229-kemoterapiden-100-kat-daha-etkiliinanilmaz-bitki

[19] ***, http://maiatsiklauri.blogcu.com/kanserden-insan-nasil-kurtulur/3400785

[20] ***, http://www.infethiye.net/turkish/notlar/kronik-hastaliklarin-gizli-sebepleri2.htm\#ixzz4SkK1PSm8

[21] Koçyiğit A, Eksojen Antioksidanlar İki Yönü Keskin Kılıçlardır, Bezmialem Science 2(2016), pp. $70-5$

[22] Karadağ M., Türközü D., Topağaç K. D..). Bitkiler ve İlaç Etkileşimleri. Göztepe Tip Dergisi 28 (2013), 4, pp.164-170.

[23] Joshi R, Medhi B., Natural product and drugs interactions, its clinical implication in drug therapy management, Saudi medical journal, 29 (2008), 3, pp.128-132

[24] Özerol E, Sitokrom P450 Monooksinejaz Enzim Sistemleri, Journal of Turgut Özal Medical Center, 3(1996), 3, pp.257-275

[25] ***, Hacettepe University Cancer Institute, http://www.prevonko.hacettepe.edu.tr/reishi.php

[26] ***, http://www.kanseroloji.com/onemli-kanserde-bitkisel-karisimlar-kullanmayin-2165.html Erişim Tarihi 9.12.2016

[27] Jones JL, Daley BJ, Enderson BL. Genistein inhibits tamoxifeneffects on cellproliferation and cell cyclearrect in T47D breast cancer cells , Am Surg, 68 (2002), 6, pp.577-8 